\title{
Sınıf Öğretmeni Adaylarının Çevre Öz Yeterlik Algılarının Çeşitli Değişkenler Açısından İncelenmesi
}

\section{Investigating of Preservice Elementary Teachers' Environmental Self-Efficacy Perceptions in Terms of Various Variables}

\author{
Seda OKUMUŞ \\ Atatürk Üniversitesi, Kazım Karabekir Eğitim Fakültesi, Matematik ve Fen Bilimleri Eğitimi Bölümü, Fen \\ Bilgisi Eğitimi ABD, Erzurum e-posta: seda.okumus@atauni.edu.tr \\ Bilge ÖZTÜRK \\ Bayburt Üniversitesi Matematik ve Fen Bilimleri Ĕ̆itimi Bölümü, Fen Bilgisi Eğitimi ABD, Bayburt, e- \\ posta:bilgeozturk25@gmail.com
}

Atıf: Okumuş, S. ve Öztürk, B. (2019). Sınıf öğretmeni adaylarının çevre öz yeterlik algılarının çeşitli değişkenler açısından incelenmesi. E-Kafkas Ĕ̈itim Araştırmaları Dergisi, 6(2), 9-18.

Gönderi Tarihi: 05.07.2019

Kabul Edilme Tarihi: 27-09-2019

DOI: $10.30900 /$ kafkasegt.587686

\section{Özet}

$\mathrm{Bu}$ araştırmanın amacı sınıf öğretmeni adaylarının çevre eğitimine yönelik öz yeterliklerini çeşitli değişkenler açısından belirlemektir. Araştırmada nicel araştırma yöntemlerinden tarama deseni kullanılmıştır. Araştırmanın örneklemini Bayburt Üniversitesi Eğitim Fakültesi Sınıf Öğretmenliği Lisans Programının farklı sınıf seviyelerinde öğrenim gören 274 (1.sınıftan 74, 2.sinıftan 72, 3.sınıftan 65 ve 4.sinıftan 63) sınıf öğretmeni adayı oluşturmaktadır. Araştırmada veri toplamak amacıyla Özdemir, Aydın ve Akar Vural'ın (2009) geliştirdiği Çevre Eğitimi Öz Yeterlik Algısı Ölçeği (ÇÖYÖ) kullanılmıştır. ÇÖYÖ, Akademik Yetkinlik Algıs1- AYA, Sorumluluk Algıs1- SA, Öğretici Yetkinlik Algıs1- ÖYA ve Yönlendirebilme AlgıS1- YA olmak üzere dört alt boyuttan oluşmaktadır. ÇÖYÖ’nün güvenirliği araştırmacılar tarafindan tekrar hesaplanmış ve ölçeğin tamamının güvenirliği $\alpha=0,81$ olarak belirlenmiştir. Alt boyutlarda $\alpha$, AYA ve SA için 0,85 , ÖYA için 0,88 ve YA için 0,80 olarak hesaplanmıştır. ÇÖYÖ’nün anlamlılık analizi için tek yönlü ANOVA, Kruskall-Wallis ve Bağımsız Örneklem- t testi kullanılmıştır. Araştırmada sınıf öğretmeni adaylarının çevre öz yeterlik algılarının, sınıf seviyesine ve cinsiyete göre değişkenlik göstermediği tespit edilmiştir.

Anahtar Sözcükler: Sinıf ögretmeni adayl, çevre, öz yeterlik, algı.

\begin{abstract}
The aim of this study was to determine the preservice elementary teachers' self-efficacy towards environmental education in terms of various variables. In the research, survey design, one of the quantitative research methods, was used. The sample of the study consisted of 274 preservice elementary teachers who are studying at different grade levels ( $741^{\text {st }}$ grade, $722^{\text {nd }}$ grade, $653^{\text {rd }}$ grade, and $634^{\text {th }}$ grade) of Bayburt University Faculty of Education Classroom Teaching Undergraduate Program. In order to collect data, Environmental Education Self-Efficacy Perception Scale (EESPS) which was developed by Aydin and Akar Vural (2009) was used. The EESPS consisted of four subscales as Academic Competence Perception- ACP, Responsibility Perception- RP, Instructive Competence Perception- ICP, and Guidance Perception- GP. The reliability of the EESPS was calculated again by researchers and the whole reliability of the EESPS found as .81. For subscales, the reliability was calculated and $\alpha$ was found as.85 for ACP and RP, .88 for ICP and .80 for GP. For the analysis of the data obtained from EESPS, firstly, normality analysis was performed, the Kolmogorov-Smirnov normality test was applied. Then, One-way ANOVA, Kruskal-Wallis, and Independent Sample t-test were used for significance analysis. In this study, preservice primary teachers' perceptions of environmental self-efficacy did not vary in terms of grade level and gender.
\end{abstract}

Keywords: Preservice primary teachers, environment, self-efficacy, perception. 


\section{GíRiş}

Çevre, günlük yaşamda birçok yerde karşılaşılan ve üzerine farklı anlamlar yüklenen bir kavramdır. Yeşilyurt, Gül ve Demir'e (2013) göre canlı ve cansız öğelerin birlikte oldukları ve etkileşimde bulundukları ortam olan çevre; canlıların sosyal, kültürel, biyolojik ve ekonomik faaliyetlerini sürdürdükleri, üreme, beslenme ve barınma gibi temel yaşam gereksinimlerini karşıladıkları yer olarak ifade edilmektedir (Yıldız, Sipahioğlu ve Yılmaz, 2000). Canlıların yaşamsal olarak bağlı oldukları çevre, canlıları etkileyen ve farklı yollarla canlılar tarafından etkilenen ortamdır (Güney, 2004). Bu ortamda canlı ve cansızlar arasındaki etkileşim üzerinde en önemli rolü insanlar üstlenmektedir. İnsanlar çevre üzerinde bütün canlılardan daha fazla etkiye sahiptir ve bu nedenle belirli bir çevre bilinciyle yetişmelerinin gerekli olduğu düşünülmektedir.

Bireylerin belirli bir çevre bilinciyle yetişmeleri için, eğitimin bütün kademelerinde bu konu üzerine bir odaklanma olduğu dikkat çekmektedir. Nitekim ilkokul programlarından lisans programlarına kadar çok geniş bir yelpaze göz önüne alındığında programlar içerisinde çeşitli şekillerde bireylerde çevre bilicinin geliştirilmesi için farklı konu, kazanım ve derslere yer verildiği görülmektedir (Milli Eğitim Bakanlığı [MEB], 2018; Yüksek Öğretim Kurumu [YÖK], 2018). Dünya devletlerinin çevre ve çevre bilinci üzerine odaklanmaları 1970'li yıllardan itibaren önem kazanmıştır (Palmer, 2003). Çevre eğitiminin önemi ilk olarak 1992 yılında düzenlenen Rio Konferansı'nda vurgulanmış, sürdürülebilir kalkınma için çevre eğitiminin şart olduğu ifade edilmiş (Ahi ve Özsoy, 2015; Eilam ve Trop, 2012), ardından tüm ülkelerde bu alana özel bir önem verilmeye başlanmıştır. Çevre eğitimi alanında ulusal ve uluslararası literatürde çeşitli araştırmalar yürütülmüştür. Bu araştırmalarda daha çok çevreye yönelik tutumlar çeşitli değişkenler bakımından incelenmiş ve öğrenciler (Ağtaş, Bektaş ve Güneri, 2019; Akıllı ve Yurtcan, 2009; Atasoy ve Ertürk, 2008; Gök ve Afyon, 2015; Kuhlemeier, Bergh ve Lagerweij, 1999; Sağsöz ve Doğanay, 2019; Tahiroğlu, Yıldırım ve Turhan, 2010; Tikka, Kuitunen ve Tynys, 2000), öğretmen adayları (Başaran Uğur, Bektaş ve Güneri, 2019; Evans ve Tribble, 1986; Genç ve Genç, 2013; Kahyaoğlu ve Özgen, 2012; Karademir, 2016; McKeown-Ice 2010; Mudasiru, 2005; Öztürk ve Öztürk, 2015; Sargın vd., 2016; Şama, 2003) ve öğretmenlerle (Ahi ve Özsoy, 2015; Gül, Çobanoğlu, Aydoğmuş ve Türk, 2018; Ko ve Lee, 2003) çalışılmıştır. Bazı çalışmalarda çevreye yönelik tutumlarda cinsiyet değişkeni bakımından farklılık görülürken (Ağtaş vd., 2019; Güler, 3013; Kahyaoğlu, 2011; Malhotra ve Chabra, 2014; Willuweit, 2009), bazılarında sınıf seviyesi (Akıllı ve Yurtcan, 2009; Aydın, 2008), okul türü (Gök ve Afyon, 2015; Şahin ve Doğu, 2018) ve mesleki deneyim (Ahi ve Özsoy, 2015; Aydın, 2008) gibi değişkenlerde farklılık görülmüştür.

Bireylerde etkili bir çevre bilincinin oluşması küçük yaşlarda onlara aşılanan duygularla mümkündür. Bu görüşten yola çıkarak, çocuklarda çevre bilincinin gelişmesi için ilkokul programlarına farklı içeriklerin entegre edilmesi bu yönden olumlu bir durum olarak görülebilir. İlkokul programlarındaki çevre bilincini öğrencilere kazandıracak olan kişilerin sınıf öğretmenleri ve sınıf öğretmeni adayları olduğu gerçeğinden yola çıkılarak, sınıf öğretmenliği lisans programının içeriğine bakıldığında programda çevre eğitimine ayrı bir önem verildiği fark edilebilir. Özellikle sınıf öğretmenleri öğrencilere çevre bilinci kazandıracak en önemli aktörlerin başında gelmektedir. "Ağaç yaş iken eğilir” atasözünden yola çıkarak çevreye karşı olumlu tutumların geliştirilmesinin küçük yaşlardan itibaren başlamasının bireyin görüşlerini şekillendirmede etkili olduğu düşünülmektedir. Bu bakımdan sınıf öğretmenlerinin çevre konusunda öz yeterlik algılarının yüksek olmasının, öğrencilerine çevre bilinci kazandırmada etkili olacağı söylenebilir. Sınıf öğretmeni adaylarının çevre öz yeterlik algılarının yüksek olması göreve başladıklarında çevreye yönelik olumlu tutum sergileyen bireyler yetiştirmeleri bakımından önemlidir. Ayrıca ülkemizde göreve yeni başlayan sınıf öğretmenlerinin genellikle köyler ve beldeler gibi ekonomik olarak daha düşük bölgelerde görev yapacakları göz önüne alınırsa, bu kesimlerdeki halkın eğitimi için öğretmen adaylarının gerekli bilinci önceden kazanması önemlidir. Çevre Eğitimi dersi Sınıf Öğretmenliği Lisans Programı'nda uzun zamandır yer almaktadır. 2018 yılında Eğitim Fakülteleri Lisans Programlarında güncelleme yapılmış olup, Sınıf Öğretmenliği Lisans Programında yer alan "Çevre Eğitimi”" dersi yerini ve içeriğini aynen korumuştur. Dolayısıyla program çerçevesinde sınıf öğretmeni adaylarında belli bir çevre bilincinin yerleştirilmesinin hedeflendiği ve onların da bu bilinçle gelecek nesilleri yetiştirmelerinin amaçlandıği gerçeği ortaya çıkmaktadır. Sınıf öğretmeni adaylarının bahsedildiği gibi çevre bilinciyle yetişmeleri, karşımıza öz yeterlik kavramını buna bağlı olarak çevre öz yeterliği kavramını çıkarmaktadır.

Öz yeterlik sosyal öğrenme kuramının ana kavramlarından biridir ve bireyin belli bir performansı yerine getirmek için gerekli yeteneklere sahip olduğu konusunda kendine olan inancı şeklinde ifade edilmektedir (Bandura, 1997). Jinks ve Morgan'a (1997) göre bazı faaliyetlerin yerine getirilmesinde kişide gelişen güven duygusu olarak ifade edilen öz yeterlik, bireyin yeni karşılaştığı bir durumu başarmada kendisiyle ilgili beklentileri şeklinde de tanımlanmaktadır (Tschannen-Moren ve Hoy, 2001). Bandura (1993) öz yeterliğin bireylerin yaptıkları işlerdeki kararlarını belirlemede önemli bir rol üstlendiğini; bireylerin düşüncelerini, duygularını ve kendilerini motive etme biçimlerini etkilediğini dile getirmiştir (Bandura, 1997). Öz yeterliğin gelişmiş olmasının bireyin performansını olumlu etkilediği, başarılı olması için gerekli görülen motivasyon kaynağını sağladığı ve yine bireyi etkileyen olumsuz düşüncelerin azalması üzerinde etkili olduğu vurgulanmakta, öz yeterliğin düşük olması durumunda ise bireyin önüne çıkan güçlükleri yenmede zorlandığ ifade edilmektedir (Bussey ve Bandura, 1999). Ayrıca öz yeterliğin öğretmenlerin sınıf içerisindeki uygulamalarını etkilediği ifade edilmektedir (Kahyaoğlu, 2011). Ulusal ve uluslararası literatürdeki çalışmalar öz yeterlikle ilgili vurgulan bu noktaları desteklemektedir. 
Örneğin, Buluç ve Demir (2015) ilkokul ve ortaokul öğretmenleriyle yürüttükleri çalışmalarında öğretmenlerin öz yeterliği ile iş doyumları arasında pozitif bir ilişkinin olduğunu rapor etmiştir. Aldan Karademir, Deveci ve Çaylı (2018) ortaokul öğrencilerinin akademik öz yeterliklerinin orta seviyede olduğunu; Şişman (2009) öz yeterliğin öğretmenler için önemini ve bu bakımdan öğretmen yetiştiren kurumların bireyin öz yeterliğini geliştirecek şekilde yapılandırılması gerektiğini ifade etmişlerdir. Zajocava, Lynch ve Espenshade (2005) ise akademik anlamda bireyin kendine olan öz yeterliğinin akademik başarısını arttırdığını ortaya koymuşlardır.

Öz yeterlik kavramının birey üzerindeki etkilerinden yola çıkılırsa, çevre eğitimi konusunda bireylerin sahip olduğu öz yeterliğin hem kendileri hem de içinde bulundukları toplum açısından ne derece önemli olduğu fark edilebilir. Çevre eğitimiyle tüm bireylerin çevre konusunda bilinçlendirilmesi, bilgilendirilmesi (Güler, 2009) ve belirli davranış değişiklikleri kazanmaları hedeflenmektedir. Bu hedefler kapsamından bireylerde çevre konusunda iyi bir öz yeterlik algısının oluşturulmasıyla, çevreye karşı daha duyarlı nesillerin yetiştirilmesinin önü açılmış olacaktır. Bu bağlamda sınıf öğretmeni adaylarının çevre konusunda öz yeterliklerinin belirli bir düzeyde olmasının gerekli ve önemli olduğu düşünülmektedir. Literatürde daha çok öğrencilerin, öğretmen adaylarının ve öğretmenlerin çevreye yönelik tutumları farklı değişkenler açısından incelendiği için çevre eğitimine yönelik öz yeterlikle ilgili fazla çalışma tespit edilmemiştir. Bu bakımdan bu çalışmanın literatüre katkı sağlayacağı düşünülmektedir. Aydın (2008) sınıf öğretmenleri ve sınıf öğretmeni adaylarının çevre yönetimine yönelik öz yeterlik inançlarının hayatlarına rehber olan değerlere ve zamana göre değişip değişmediğini belirlemek için bir çalışma yürütmüştür. Çalışmada çevre eğitimi öz yeterlik algısının belirlenmesinde farklı alt boyutlarda çevre eğitimi dersini alan sınıf öğretmeni adaylarının dersi almayan adaylara göre ölçekten daha yüksek puan aldıklarını ortaya koymuştur. Ayrıca meslekte yıl olarak daha az kıdemli olan sınıf öğretmenlerinin (1-10 yıl) daha çok kıdemli olan sınıf öğretmenlerine (11-20 yıl) göre, öz yeterlik düzeylerinin daha yüksek olduğunu belirlemiş, cinsiyet bakımından gruplar arasında cinsiyete göre farklılık olmadığını vurgulamıştır. Benzer şekilde, Kahyaoğlu (2011) fen bilgisi ve sınıf öğretmeni adaylarının çevre öz yeterliklerini karşılaştırdığı çalışmasında, öğretmen adaylarının öz yeterliklerinin orta seviyede olduğunu ve fen bilgisi öğretmen adaylarını öz yeterliklerinin daha yüksek olduğunu tespit etmiştir.

Zaman her geçen gün insanlığın aleyhine işlemekte ve zamana bağlı olarak insanların çevre üzerindeki etkileri artmakta ve yıldan yıla ve bölgeden bölgeye farklılaşmaktadır. Çevre duyarlılığı konusunda bireylerde gereken bilincin oluşturulamamasının sonucu olarak çevre sorunlarındaki artış kaçınılmaz hale gelmiştir. Bu bakımdan Aydın'ın (2008) yılında sınıf öğretmeni adaylarıyla yürüttüğü çalışmanın sonuçlarının günümüzde nasıl değiştiği ya da değiş̧ip değişmediği merak uyandırmaktadır. Buradan hareketle araştırmanın amacı; sınıf öğretmeni adaylarının çevre eğitimine yönelik öz yeterlik algılarının sınıf seviyesi ve cinsiyet değişkeni açısından tespit etmek olarak belirlenmiştir.

Araştırmanın ana problem cümlesi: "Sınıf öğretmeni adaylarının çevre eğitimi öz yeterlik algıları nasıldır? şeklindedir. Alt problemler ise:

1. Sınıf öğretmeni adaylarının çevre eğitimi öz yeterlik algılarında sınıf seviyesi değişkeninin etkisi var midir?

2. Sınıf öğretmeni adaylarının çevre eğitimi öz yeterlik algılarında cinsiyet değişkeninin etkisi var mıdır?

olarak belirlenmiştir.

\section{YÖNTEM}

\section{Arașturma Deseni}

Araştırmada sınıf öğretmeni adaylarının çevre eğitimi dersi ile ilgili öz yeterlik algılarının ortaya çıkarılması amaçlandığı için nicel araştırma yöntemlerinden tarama deseni kullanılmışıtır. Temelde betimleyici bir yapıya sahip olan tarama deseni; toplumların, kurumların ve nesnelerin yapısını tanımlamak (Özdemir, 2014), bir olay veya bir konuyla ilgili belli bir grubun fikirlerini belirlemek ve o konuyla ilgili belirlenen grubun yetenek, ilgi, tutum, beceri ve algı gibi özelliklerini tespit etmek amacıyla kullanılmaktadır (Büyüköztürk, Kılıç Çakmak, Akgün, Karadeniz ve Demirel, 2014).

\section{Çalışma Grubu}

Araştırmanın örneklemini 2018-2019 bahar yarıyll Bayburt Üniversitesi Sınıf Öğretmenliği Lisans Programında öğrenim gören 274 sınıf öğretmeni adayı oluşturmaktadır. Araştırmaya 1.sınıftan 74 (51 kız, 23 erkek), 2.sınıftan 72 (47 kız, 25 erkek), 3.sinıftan 65 (39 kız, 26 erkek) ve 4.sınıftan 63 (41 kız, 22 erkek) sınıf öğretmeni adayı katılmıştır. Bu araştırmada örneklem seçme işleminde ulaşılabilir (uygun) örnekleme yöntemi kullanılmıştır. Para, zaman ve işgücü kaybını önlemeyi temel amaç edinen (Büyüköztürk vd., 2014) bu örnekleme yönteminde, kolaylıkla ulaşılabilen ve araştırmaya katılmaya gönüllü bireyler örneklem grubuna alınır (Johnson ve Christensen, 2014). Araştırmacılardan birinin görev yaptığı üniversite olması bakımından uygun örnekleme yöntemi tercih edilmiştir.

\section{Veri Toplama Aracı}

Veri toplamak amacıyla Özdemir, Aydın ve Akar Vural'ın (2009) likert tipinde geliştirdiği Çevre Eğitimi Öz Yeterlik Algısı Ölçeği (ÇÖYÖ) kullanılmıştır. Ölçekteki maddeler 5=Tamamen Katılıyorum, 4=Katılıyorum, 
3=Biraz Katılıyorum, 2=Katılmıyorum ve 1=Kesinlikle Katılmıyorum şeklinde puanlandırılmıştır. Ölçekten alınabilecek en yüksek puan 75'tir. Ölçek, "Akademik Yetkinlik Algıs1- AYA", "Sorumluluk Algısı- SA", "Öğretici Yetkinlik Algıs1- ÖYA" ve "Yönlendirebilme Algıs1 - YA" olmak üzere dört alt boyuttan oluşmaktadır. AYA'da altı, SA, ÖYA ve YA'da üç olmak üzere toplamda 15 madde bulunmaktadır. Bunlardan YA'daki 13, 14 ve 15. madde ters maddedir. Geçerlik ve güvenirlik çalışmaları Özdemir vd. (2009) tarafindan yapılmıştır. Buna göre Özdemir vd. (2009) ölçeğin genel güvenirlik katsayısını $\alpha=0,76$ olarak belirlemişlerdir. Alt boyutlar bazında ise AYA için $\alpha=0,79$, SA için $\alpha=0,86$, ÖYA için $\alpha=0,74$ ve YA için $\alpha=0,68$ olarak belirlemişlerdir. Bu çalışmada ÇÖYÖ’nün güvenirliğine tekrar bakılmıştır. Buna göre ölçeğin genel güvenirliği $\alpha=0,81$; alt boyutlarda ise AYA ve SA için $\alpha=0,85$, ÖYA için $\alpha=88$ ve YA için $\alpha=0,80$ olarak hesaplanmıştır.

\section{Verilerin Analizi}

Verilerin analizi için öncelikle ÇÖYÖ'den elde edilen verilerin normal dağılıma uygunluğu belirlenmiştir. Normallik için ÇÖYÖ verilerine Kolmogorov-Smirnov normallik testi uygulanmıştır. Anlamlılık analizi için tek yönlü ANOVA, Kruskall-Wallis ve Bağımsız Örneklem- t testi uygulanmıştır.

\section{BULGULAR}

Araştırmadan elde edilen bulgular alt problemlere göre oluşturulmuştur. Birinci alt probleme göre sınıf öğretmeni adaylarının çevre eğitimi öz yeterlik algılarının sınıf seviyelerine göre değişimi hem ölçeğin toplam puanları hem de alt faktörler bakımından, ikinci alt probleme göre her bir sınıf seviyesinde cinsiyet değişkeni bakımından incelenmiştir.

Sınıf Ö̆̆retmeni Adaylarının Çevre Ĕ̆̈itimi Öz, Yeterlik Algılarının Sınıf Seviyesine Göre İncelenmesi

$\mathrm{Bu}$ kısımda öncelikle ÇÖYÖ’den elde edilen verilerin normal dağılımına uygunluğu belirlenmeye çalışılmıştır. $\mathrm{Bu}$ amaçla her bir sınıf seviyesindeki öğretmen adayı sayısı 30'dan fazla olduğu için veriler Kolmogorov- Smirnov normallik testi ile analiz edilmiştir. Tablo 1'de ÇÖYÖ'den elde edilen bulgular verilmiştir.

Tablo 1.

ÇÖYÖ’nün Kolmogorov-Smirnov normallik testi sonuçlart

\begin{tabular}{llll}
\hline Sinıflar & İstatistik & df & p \\
\hline 1. sinıf & .85 & 74 & .20 \\
2. sinıf & .60 & 72 & .20 \\
$3 . \sin 1 f$ & .10 & 65 & .19 \\
4.sinif & .11 & 63 & .07 \\
\hline
\end{tabular}

Tablo 1'e göre tüm sınıf seviyelerinde verilerin normal dağılıma uygun olduğu görülmektedir. Sınıflar arasında ÇÖYÖ verileri bakımından anlamlı fark olup olmadığının belirlenmesi amacıyla grup sayısı üçten fazla olduğu için tek yönlü ANOVA testi yapılmıştır. ÇÖYÖ verilerinin betimsel istatistikleri Tablo 2'de sunulmuştur.

Tablo 2.

ÇÖYÖ verilerinin betimsel istatistikleri

\begin{tabular}{lccc}
\hline Sinıflar & $\mathbf{n}$ & $\mathbf{X}$ & SS \\
\hline 1.sinıf & 74 & 51.97 & 7.898 \\
2. sinıf & 72 & 49.85 & 7.898 \\
3.sinıf & 65 & 50.91 & 7.664 \\
4.sinıf & 63 & 50.17 & 7.914 \\
Toplam & 274 & 50.75 & 7.849 \\
\hline
\end{tabular}

Tablo 2'ye göre sınıf ortalamalarının birbirine oldukça yakın olduğu görülmektedir. Tablo 3'te ÇÖYÖ verilerine uygulanan tek yönlü ANOVA testinin sonuçları verilmiştir.

Tablo 3.

ÇÖYÖ verilerinin tek yönlü ANOVA sonuçlart

\begin{tabular}{llllll}
\hline & Kareler toplamı & df & Karelerin ortalaması & F & p \\
\hline Gruplar arası & 191.833 & 3 & 63.944 & 1.038 & .376 \\
Grup içi & 16625.791 & 270 & 61.577 & & \\
Toplam & 16817.624 & 273 & & & \\
\hline
\end{tabular}

Tablo 3'e göre gruplar arasında ÇÖYÖ verileri bakımından istatistiksel olarak anlamlı bir farklılık bulunmamıştır ( $\mathrm{p}>.05)$. 
Stnıf Öğretmeni Adaylarının Çevre Eğitimi Öz Yeterlik Algılarının ÇÖYÖ’nün Alt Boyutlarındaki Verilere Göre İncelenmesi

Öncelikle ÇÖYÖ'ün alt boyutlarından elde edilen verilerin normal dağılımına uygunluğu tespit edilmiştir. $\mathrm{Bu}$ amaçla için her bir sınıf seviyesinde öğretmen adayı sayısı 30'dan fazla olduğu için veriler KolmogorovSmirnov normallik testi ile analiz edilmiştir. Tablo 4 'te ÇÖYÖ'den elde edilen bulgular sunulmuştur.

Tablo 4.

ÇÖYÖ'nün alt boyutlarından elde edilen verilerin Kolmogorov-Smirnov normallik testi sonuçları

\begin{tabular}{lllll}
\hline Sinıflar & Alt faktörler & Istatistik & df & p \\
\hline 1. sinıf & AYA & .12 & 74 & $\mathbf{. 0 1}$ \\
& SA & .09 & 74 & .20 \\
& ÖYA & .16 & 73 & $\mathbf{. 0 0}$ \\
\multirow{4}{*}{2. sinıf } & YA & .12 & 74 & $\mathbf{. 0 2}$ \\
& AYA & .11 & 72 & $\mathbf{. 0 3}$ \\
& SA & .18 & 72 & $\mathbf{. 0 0}$ \\
& ÖYA & .20 & 72 & $\mathbf{. 0 0}$ \\
& YA & .09 & 72 & .20 \\
3. sinıf & AYA & .12 & 65 & $\mathbf{. 0 3}$ \\
& SA & .18 & 65 & $\mathbf{. 0 0}$ \\
& ÖYA & .23 & 65 & $\mathbf{. 0 0}$ \\
& YA & .17 & 65 & $\mathbf{. 0 0}$ \\
& AYA & .07 & 63 & .20 \\
& SA & .16 & 63 & $\mathbf{. 0 0}$ \\
& ÖYA & .19 & 63 & $\mathbf{. 0 0}$ \\
& YA & .12 & 63 & $\mathbf{. 0 2}$
\end{tabular}

Tablo 4'ten 1. sınıfta SA, 2. sinıfta YA ve 4. sınıfta AYA verilerinin normal dağılıma uygun olduğu ( $p>.05)$; diğer verilerin normal dağılıma uygun olmadığ 1 ( $<.05)$ görülmektedir.

Alt boyutlar bakımından sınıflar arasında anlamlı fark olup olmadığının belirlenmesi amacıyla yapılan Kruskall-Wallis testi sonuçları Tablo 5'te verilmiştir.

Tablo 5.

ÇÖYÖ'nün alt boyutlarının Kruskall-Wallis testi sonuçları

\begin{tabular}{|c|c|c|c|c|c|c|}
\hline Alt faktörler & Gruplar & $\mathbf{n}$ & Sira Ortalaması & sd & $\mathrm{X}^{2}$ & $\mathbf{p}$ \\
\hline \multirow[t]{4}{*}{ AYA } & 1.sinif & 74 & 149.25 & 3 & 3.118 & .37 \\
\hline & 2.sinif & 72 & 135.49 & & & \\
\hline & 3.sinif & 65 & 137.90 & & & \\
\hline & 4.sinif & 63 & 125.58 & & & \\
\hline \multirow[t]{4}{*}{ SA } & 1.sinif & 74 & 141.24 & 3 & 2.045 & .56 \\
\hline & 2.sinif & 72 & 127.09 & & & \\
\hline & 3.sinif & 65 & 145.08 & & & \\
\hline & 4.sinif & 63 & 137.19 & & & \\
\hline \multirow[t]{4}{*}{ ÖYA } & 1.sinif & 73 & 151.58 & 3 & 5.510 & .14 \\
\hline & 2.sinif & 72 & 122.01 & & & \\
\hline & 3.sinif & 65 & 140.48 & & & \\
\hline & 4.sinif & 63 & 133.65 & & & \\
\hline \multirow[t]{4}{*}{ YA } & 1.sinif & 74 & 144.01 & 3 & 2.785 & .43 \\
\hline & 2.sinif & 72 & 124.91 & & & \\
\hline & 3.sinif & 65 & 137.68 & & & \\
\hline & 4.sinif & 63 & 144.06 & & & \\
\hline
\end{tabular}

Tablo 5'e göre ÇÖYÖ'nün alt boyutlarda araştırma grupları arasında istatistiksel olarak anlamlı bir farklılık bulunmamıştır ( $\mathrm{p}>05$ ).

\section{ÇÖYÖ Verilerinin Cinsiyet Değisskenine Göre İncelenmesi}

ÇÖYÖ'den elde edilen verilerin cinsiyet değişkenine göre incelenmesi iki aşamada yapılmıştır. İlk kısımda tüm öğretmen adayları göz önüne alınarak, çevre eğitimine yönelik kız ve erkek sınıf öğretmeni adaylarının öz yeterlik algıları karşılaştırılmıştır. İkinci kısımda ise sınıf bazında kız ve erkek sınıf öğretmeni adaylarının çevre eğitimi öz yeterlik algıları karşılaştırılmıştır. 


\section{Tüm Sintf Seviyelerine Göre Cinsiyet Değişkeninden Elde Edilen Bulgular}

Öncelikle verilerin normal dağılıma uygunluğu belirlenmiştir. Bu amaçla kız ve erkek sınıf öğretmeni adayı sayısı 30'dan fazla olduğu için veriler, Kolmogorov- Smirnov normallik testi ile analiz edilmiştir. Tablo 6'da ÇÖYÖ'den cinsiyet bazında elde edilen bulgular verilmiştir.

Tablo 6

Cinsiyet değișkeni bakımından Kolmogorov-Smirnov normallik testi sonuçları

\begin{tabular}{llll}
\hline Cinsiyet & İstatistik & df & p \\
\hline Kiz & .04 & 178 & .20 \\
Erkek & .09 & 96 & .06 \\
\hline
\end{tabular}

Tablo 6'ya göre grupların cinsiyet verileri bakımından normal dağılma uygun olduğu görülmektedir (p>.05). Tablo 7'de cinsiyet değişkeni bakımından gruplar arasında anlamlı bir fark olup olmadığının belirlenmesi için yapılan bağımsız örneklem $t$ testi sonuçları verilmiştir.

Tablo 7.

ÇÖYÖ'nün cinsiyet değişkenine göre bağımsı örneklem t testi sonuçları

\begin{tabular}{llcccc}
\hline Cinsiyet & $\mathbf{n}$ & $\mathbf{X}$ & $\mathbf{S S}$ & $\mathbf{t}$ & $\mathbf{p}$ \\
\hline Kiz & 178 & 50.41 & 7.461 & -.971 & .33 \\
Erkek & 96 & 51.38 & 8.526 & & \\
\hline
\end{tabular}

Tablo 7'ye göre çevre eğitimi öz yeterlik algılarının cinsiyete göre değişimi bakımından araștırma grupları arasında istatistiksel olarak anlamlı bir farklılık belirlenmemiştir $(\mathrm{p}>.05)$.

\section{Cinsiyet değişkenine göre sinıf bazında değerlendirmeden elde edilen bulgular}

Öncelikle verilerin normal dağılıma uygunluğu belirlenmiştir. Bu amaçla kız ve erkek öğretmen adayı sayısı 30'dan fazla olduğu için veriler Kolmogorov- Smirnov normallik testi ile analiz edilmiştir. Tablo 8'de sınıf seviyesine göre cinsiyet bakımından ÇÖYÖ'den elde edilen bulgular verilmiştir.

Tablo 8.

Sinıf seviyesine göre cinsiyet değiskeni bakımından Kolmogorov- Smirnov normallik testi sonuçları

\begin{tabular}{lllll}
\hline Sinıflar & Cinsiyet & İstatistik & df & p \\
\hline 1.sinıf & Kız & .08 & 51 & .20 \\
& Erkek & .11 & 23 & .20 \\
$2 . \sin ı f$ & Kiz & .07 & 47 & .20 \\
& Erkek & .09 & 25 & .20 \\
3. sinıf & Kiz & .08 & 39 & .20 \\
& Erkek & .17 & 26 & .06 \\
$4 . \sin ı f$ & Kız & .09 & 41 & .20 \\
& Erkek & .12 & 22 & .20 \\
\hline
\end{tabular}

Tablo 8'e göre tüm sınıf seviyelerinde verilerin normal dağılıma uygun olduğu ( $\mathrm{p}>.05)$ görülmektedir. Bu nedenle anlamlılık analizi için verilere Bağımsız Örneklem- $t$ testi yapılmıştır. Tablo 9'da Bağımsız Örneklem$\mathrm{t}$ testi sonuçları verilmiştir.

Tablo 9.

ÇÖYÖ'nün bağımsız örneklem- t testi sonuçları

\begin{tabular}{lllcccc}
\hline Sinıflar & Cinsiyet & n & X & SS & t & p \\
\hline 1.sinıf & Kiz & 51 & 51.33 & 7.636 & -1.038 & .30 \\
& Erkek & 23 & 53.39 & 8.452 & & \\
2. sinıf & Kiz & 47 & 49.09 & 8.400 & -1.125 & .27 \\
& Erkek & 25 & 51.28 & 6.786 & & \\
3. sinıf & Kiz & 39 & 51.15 & 7.485 & .310 & .79 \\
& Erkek & 26 & 50.54 & 8.061 & & \\
$4 . \sin ı f$ & Kiz & 41 & 50.07 & 5.939 & -.138 & .89 \\
& Erkek & 22 & 50.36 & 10.848 & & \\
\hline
\end{tabular}

Tablo 9'a göre cinsiyet değişkeni bakımından sınıf seviyelerine göre grupların verileri analiz edildiğinde, araştırma grupları arasında istatistiksel olarak anlamlı bir farklılık olmadığı görülmüştür (p>.05). 


\section{TARTIŞMA, SONUÇ VE ÖNERILER}

Bu araştırmada sınıf öğretmeni adaylarının çevre eğitimine yönelik öz yeterlik algıları sınıf seviyesi ve cinsiyet değişkeni bakımından incelenmiştir. Araştırmanın ilk alt probleminde sınıf öğretmeni adaylarının çevre eğitimine yönelik öz yeterlik algıları sınıf seviyesi bakımından incelenmiştir. Buna göre sınıf seviyeleri bakımından araştırma grupları arasında istatistiksel olarak anlamlı bir farklılık görülmemiştir ( $\mathrm{p}>0,05)$. Çevre eğitimi dersi sınıf öğretmenliği programında 2.sınıf seviyesinde ve güz yarıyılında verilmektedir. Dolayısıyla araştırma bahar yarıyılında yapıldığı için araştırmaya katılan öğretmen adaylarından sadece 1.sınıf seviyesinde öğrenim görenler çevre eğitimi dersini almamışlardır. Bu bakımdan bu araştırmada çevre eğitimi dersini alan ve almayan öğretmen adayları arasında çevre eğitimi dersini alanlar lehine anlamlı bir farklılık beklenmekteydi. Ancak sınıf seviyesine göre anlamlı bir farklılığın olmadığı görülmüştür. Bu durumun ortaya çıkmasında öğretmen adaylarının önceki öğrenim hayatlarında çevreye yönelik dersler almış olmaları etkili olabilir. Çünkü çevre bilimi ile ilgili dersler ortaokul seviyesinde fen bilimleri ve sosyal bilimler derslerinde, lise seviyesinde coğrafya derslerinde yer almaktadır. Alt boyutlar bakımından yapılan analizlerde de yine sınıf seviyelerine göre sınıf öğretmeni adaylarının çevre öz yeterlik algılarında istatistiksel olarak anlamlı bir farklılık belirlenmemiştir $(p>0,05)$. Buna göre öğretmen adaylarının çevre ile ilgili olarak akademik yetkinlik, sorumluluk, öğretici yetkinlik ve yönlendirebilme algılarının benzer olduğu görülmüştür. Çevre eğitimi dersinin günlük hayatla doğrudan ilişkili bir ders olması ve yaşamın her alanında ve her döneminde insanın karşısına çıkması bireylerin çevreye karşı daha bilinçli olmaya başlamasıyla açıklanabilir. Benzer sonuçlar Deniş ve Genç (2007) ve Karademir (2016) araştırmalarında da rapor edilmiştir. Bu sonuçlardan farklı olarak, Aydın (2008) araştırmasında akademik yetkinlik ve yönlendirebilme algısı alt boyutlarında çevre eğitimi dersini alan öğretmen adaylarının kendilerini daha yeterli hissettiklerini tespit etmiştir. Bu araştırmada öğretmen adaylarının ÇÖYÖ’ye verdikleri cevaplara göre çevre eğitimi ile ilgili öz yeterlik algılarının orta seviyenin üstünde olduğu görülmektedir. Bu da, araştırmaya katılan sınıf öğretmeni adaylarının çevre bilincine sahip ve çevre eğitimi konusunda kendilerini yeterli hisseden bireyler olduklarını göstermektedir. Her ne kadar sınıf seviyeleri arasında anlamlı bir farklılık olmasa da öğretmen adaylarının çevre eğitimine yönelik algılarının yüksek çıkması araştırmacıların zihninde "çevre bilincine sahip öğretmenler yetişiyor düşüncesi” doğurduğu için sevindiricidir. Benzer şekilde, Kahyaoğlu (2011) araştırmasında fen bilgisi ve sınıf öğretmeni adaylarının çevreye yönelik öz yeterlik algılarının orta seviyede olduğunu belirlemiştir. Öz yeterlikle ilgili yürütülen farklı çalışmalarda öğretmen adaylarının fen bilgisi, matematik ve Türkçe öğretimi ile bilgisayar kullanımı gibi alanlarda öz-yeterliklerinin orta seviyede olduğu görülmüştür (Altunçekiç ve Koray, 2005; Sarıkaya, 2004; Seferoğlu ve Akbıyık, 2005). Öğretmenlerin dersi işlerken kendilerini daha güçlü hissettikleri öz yeterlik kavramı, öğretim açısından önemlidir. Öz yeterliği yüksek olan öğretmenin kendini daha iyi ifade edebildiği ve karşılaştıkları problemlerle daha rahat başa çıkabileceği düşünüldüğünde, öğretmenlerin öz yeterliklerini artırıcı faktörlerin işe koşulmasının önemi artmaktadır. Bu bağlamda öğretmenlik mesleğine başlamadan önce öğretmen adaylarının çevre eğitimi ile ilgili öz yeterliklerini artırmanın faydalı olacağı düşünülmektedir.

Araştırmanın ikinci alt probleminde sınıf öğretmeni adaylarının çevre eğitimine yönelik öz yeterlik algıları cinsiyet bakımından incelenmiştir. Buna göre çevre eğitimi öz yeterlik algısı bakımından tüm öğretmen adayları arasında ve her bir sınıf seviyesinde kız ve erkek öğretmen adayları arasında istatistiksel olarak anlamlı bir farklılık belirlenmemiştir ( $\mathrm{p}>0,05)$. Bu araştırmanın sonuçlarına paralel olarak çevre öz yeterlik algılarında cinsiyetin bir etkisinin olmadığı Aydın (2008), Kahyaoğlu (2011) ve Karademir (2016) araştırmalarında da rapor edilmiştir. Bununla birlikte Öztürk, Öztürk ve Şahin (2015) araştırmalarında öz yeterlikle ilgili erkek öğretmen adayları lehine anlamlı bir farklılık belirlemişlerdir. Ayrıca öz yeterlikle ilgili yürütülen bazı çalışmalarda kızların öz yeterliğinin (Evans ve Tribble, 1986) bazılarında ise erkeklerin öz yeterliğinin daha yüksek olduğu (Morgil, Seçken ve Yücel, 2004) tespit edilmiştir.

İlkokul seviyesinde yapılan araştırmalarda öğrencilerin çevreye yönelik algılarının yüksek olduğu, çevre sorunlarına karşı duyarlı oldukları (Sever ve Yalçınkaya, 2017) ve bu sebeple ilkokul seviyesinde çevre eğitimine gerekli önemin verilmesi vurgulanmaktadır. $\mathrm{Bu}$ araştırmanın sonucunda sınıf öğretmeni adaylarının çevre eğitimine yönelik öz yeterlik algılarının orta seviyenin üzerinde olduğu, sınıf seviyesi ve cinsiyet değişkenine göre ise farklılık göstermediği tespit edilmiştir. Sınıf eğitimi alanında çevre eğitimine gereken önemin verilmesinin hem öğrenci hem öğretmen adayı hem de öğretmenlerin öz yeterlik algılarına olumlu etki edeceği düşünülmektedir. Bu bakımdan ilkokuldan lisans seviyesine kadar çevre bilinci kazandırmak önemlidir. Öğretmen adaylarına çevre bilinci kazandırılması için fakülte denetiminde veya sivil toplum örgütleri bünyesinde çeşitli sosyal sorumluluk projeleri yürütülebilir. Araştırmacılar bu projeler kapsamında öğretmen adaylarının çevreye yönelik tutum ve yaklaşımlarındaki değişimi veya gelişimi belirleyebilir.

İlerleyen araştırmalar için çevre eğitimine yönelik öz yeterlikleri artırmaya yönelik bazı öneriler şu şekildedir: Çevre eğitimi dersi kapsamında farklı yöntem ve tekniklerin kullanılarak sınıf öğretmeni adaylarının çevre eğitimine yönelik öz yeterliklerindeki değişim belirlenebilir. Sınıf öğretmenleriyle çevre eğitimine yönelik çeşitli çalışmalar yürütülerek öğretmenlerin çevre eğitimini öğrencilerine öğretmenlerindeki öz yeterliklerine bakılabilir. Ayrıca ilkokul öğrencilerinin çevre öğrenmeye yönelik öz yeterliklerine farklı değişkenler açısından bakılabilir. 


\section{KAYNAKÇA}

Ağtaş, B., Bektaş, O. ve Güneri, E. (2019). Ortaokul öğrencilerinin çevreye yönelik tutum düzeylerinin belirlenmesi. Online Fen Eğitimi Dergisi, 4(1), 66 - 85.

Ahi, B. ve Özsoy, S. (2015). İlkokullarda görev yapan öğretmenlerin çevreye yönelik tutumları: cinsiyet ve mesleki kıdem faktörü. Kastamonu Eğitim Dergisi, 23(1), 31-56.

Akıllı, M. ve Yurtcan, M.T. (2009). İlköğretim fen bilgisi öğretmeni adaylarının çevreye karşı tutumlarının farklı değişkenler açısından incelenmesi (Kazım Karabekir Eğitim Fakültesi örneği). Erzincan Eğitim Fakültesi Dergisi, 11(2), 119- 131.

Aldan Karademir, Ç., Deveci, Ö. ve Çaylı, B. (2018). Ortaokul öğrencilerinin öz-düzenlemeleri ve akademik özyeterliklerinin incelenmesi. Kafkas Üniversitesi, e - Kafkas Ĕ̆itim Araştırmaları Dergisi, 5(3), 14-29.

Altunçekiç, A., Yaman, S. ve Koray, Ö. (2005). Öğretmen adaylarının öz-yeterlik inanç düzeyleri ve problem çözme becerileri üzerine bir araştırma- Kastamonu ili örneği. Kastamonu Eğitim Dergisi, 13(1), 93-102.

Atasoy, E. ve Ertürk, H. (2008). İlköğretim öğrencilerinin çevresel tutum ve çevre bilgisi üzerine bir alan araştırması. Erzincan Eğitim Fakültesi Dergisi, 10(1), 105- 122.

Aydın, N. (2008). Sınıf ögretmeni adaylarının ve ögretmenlerinin çevre ĕgitimine yönelik öz-yeterlik inançları üzerine sınıf düzeyi, kıdem ve değer yönelimlerinin etkisi. Yayımlanmamış Yüksek lisans tezi, Adnan Menderes Üniversitesi, Aydın.

Bandura, A. (1997). Self-efficacy: The exercise of control. New York: Freeman

Bandura, A. (1993). Perceived self-efficacy in cognitive development and functioning. Educational Psychologist, 28(2), 117-148.

Başaran Uğur, R., A., Bektaş, O. ve Güneri, E. (2019). Sınıf ve fen bilgisi öğretmen adaylarının sürdürülebilir çevre tutum düzeyleri. Journal of International Social Research, 12(63), 775- 788.

Buluç, B. \& Demir, S. (2015). İlk ve ortaokul öğretmenlerinin öz-yeterlik algıları ile iş doyumları arasındaki ilişki. Ahi Evran Üniversitesi Kırşehir Ĕ̆itim Fakültesi Dergisi (KEFAD), 16(1), 289-308.

Bussey, K. ve Bandura, A. (1999). Social cognitive theory of gender development and differentiation. Psychological Review, 106, 676-713.

Büyüköztürk, Ş., Kılıç-Çakmak, E., Akgün, Ö. A., Karadeniz, Ş. ve Demirel, F. (2014). Bilimsel araştırma yöntemleri (16. Baskı). Ankara: Pegem Akademi Yayıncılık.

Deniş, H. ve Genç, H. (2007). Çevre bilimi dersi alan ve almayan sınıf öğretmenliği öğrencilerin çevreye ilişkin tutumları ve çevre bilimi dersindeki başarılarının karşılaştırılması. Mehmet Akif Ersoy Üniversitesi Ĕ̆gitim Fakültesi Dergisi, 13, 20-26.

Eilam, E. and Trop, T. (2012). Environmental attitudes and environmental behavior-Which is the horse and which is the cart?. Sustainability, 4, 2210-2246.

Evans, E.D. and Tribble, M. (1986). Perceived teaching problems, self-efficacy and commitment to teaching among preservice teachers. Journal of Educational Research, 80, 81-85.

Genç, M. ve Genç, T. (2013). Sınıf öğretmenliği öğrencilerinin çevreye yönelik tutumlarının belirlenmesi. Asya Öğretim Dergisi, 1(1), 9-19.

Gök, E. ve Afyon, A. (2015). İlköğretim öğrencilerinin çevre bilgisi ve çevresel tutumları üzerine alan araştırması. Türk Fen Eğitimi Dergisi, 12(4), 77-93.

Gül, S., Çobanoğlu, İ.H., Aydoğmuş, M. ve Türk, H. (2018). Sınıf öğretmenlerinin çevreye yönelik tutumlarının incelenmesi: Samsun ili örneği. Ondokuz Mayıs Üniversitesi Eğitim Fakültesi Dergisi, 37(2), 139-157.

Güler, T. (2009). Ekoloji temelli bir çevre eğitiminin öğretmenlerin çevre eğitimine karşı görüşlerine etkileri. Ĕ̆itim ve Bilim, 34(151), 30-43.

Güler, E. (2013). İlkögretim 8. sinıf ögrencilerinin çevre okuryazarlı̆̆ı düzeylerinin belirlenmesi ve öğrencilerin okuryazarlığı düzeylerinin çeşitli değişkenler açısından incelenmesi. Yayımlanmamış yüksek lisans tezi, Çukurova Üniversitesi, Adana.

Güney, E. (2004). Çevre sorunları coğrafyası. Ankara: Gündüz Eğitim ve Yayıncılık.

Jinks, J.L. and Morgan, V. C. (1997). Student's sense of academic efficacy and achievement in science: A useful new direction for research regarding scientific literacy?. The Electronic Journal of Science Education 1(2), Article 2.

Johnson, B. and Christensen, L. (2014). Ĕgitim araştırmaları: Nicel, nitel ve karma araştırmalar (4. Baskı). (Çev. S. B. Demir). Ankara: Eğiten Kitap.

Kahyaoğlu, M. (2011). Öğretmen adaylarının öğrenme stilleri ile çevre eğitimi öz-yeterlikleri arasındaki ilişki. Eğitim Bilimleri Araştırma Dergisi (EBAD), 1(2), 67-82.

Kahyaoğlu, M. ve Özgen, N. (2012). Öğretmen adaylarının çevre sorunlarına yönelik tutumlarının çeşitli değişkenler açısından incelenmesi. Kuramsal Ĕ̆itimbilim Dergisi, 5(2), 171-185.

Karademir, E. (2016). Eğitim fakültelerinin yapılandırılması sürecinde öğretmen adaylarının çevre bilinci ve özyeterliklerinin belirlenmesi. Ĕgitim ve Insani Bilimler Dergisi: Teori ve Uygulama, 7(13), 3-18.

Ko, A.C. and Lee, J.C. (2003). teachers' perceptions of teaching environmental issues within the science curriculum: A Hong Kong perspective. Journal of Science Education And Technology, 12(3), 187-204. 
Kuhlemeier, H., Bergh, H.V.D. and Lagerwe1j, N. (1999). Environmental knowledge, attitudes and behavior in dutch secondary education. The Journal of Environmental Education, 30(2), 6-14.

Malhotra, T. and Chabra, S. (2014). A study of responsible behaviour among b.ed. distance learners with reference to their locality, gender, stream and socio-economic status. International Women Online Journal of Distance Educa-tion, 3(2), 1-10.

McKeown-Ice, R. (2010). Environmental education in the united states: a survey of preservice teacher education programs. The Journal of Environmental Education, 32(1), 4-11.

Millî Eğitim Bakanlığı [MEB]. (2018). Hayat bilgisi dersi öğretim programı (İlkokul 1,2 ve 3. sınıflar). Ankara: MEB Yayınları.

Morgil, İ., Seçken, N. ve Yücel, A.S. (2004). Kimya öğretmen adaylarının öz-yeterlik inançlarının bazı değişkenler açısından incelenmesi. Balıkesir Üniversitesi Fen Bilimleri Enstitüsü Dergisi, 6(1), 62-72.

Mudasiru, O.Y. (2005). An investigation into teacher's self-efficacy in implementing computer education in Nigerian secondary schools. Meridian: A Middle School Technologies Journal, 8(2), 1-5.

Özdemir, Ö. (2014). Tarama yöntemi. M. Metin (Ed.), Kuramdan uygulamaya eğitimde bilimsel araştırma yöntemleri içinde (s. 77-97). Ankara: Pegem Akademi Yayıncılık.

Öztürk, T. ve Öztürk, F.Z. (2015). Öğretmen adaylarının çevre ve çevre eğitimi ile ilgili görüşleri (Ordu Üniversitesi örneği). Balıkesir Üniversitesi Sosyal Bilimler Enstitüsü Dergisi, 18(33), 115-132.

Öztürk, F. Z., Öztürk, T. ve Şahin, A. (2015). Sınıf öğretmeni adaylarının çevre eğitimi özyeterlik algılarının incelenmesi. Amasya Üniversitesi Ĕ̆itim Fakültesi Dergisi, 4(2), 293-311.

Palmer, J. A. (2003). Environmental education in the 21 st Century, theory, practice, progress and promise. New York: Routledge.

Sağsöz, G. ve Doğanay, G. (2019). İlkokul öğrencilerinin çevre ve çevre sorunlarına ilişkin görüşlerinin incelenmesi (Giresun İli Örneği). Anadolu Üniversitesi Ĕ̈itim Fakültesi Dergisi (AUJEF), 3(1), 1-20.

Sargın, S. A., Baltacı, F., Katipoğlu, M., Erdik, C., Arbatlı, M.S., Karaardıç, H., Yumuşak, A. \& Büyükcengiz, M. (2016). Öğretmen adaylarının çevreye karşı bilgi, davranış ve tutum düzeylerinin araştırılması. Education Sciences (NWSAES), 11(1), 1-22.

Sarıkaya, H. (2004). Sinıf ögretmeni adaylarının bilgi düzeyleri fen ögretimine yönelik tutum ve öz-yeterlik inançları (Yüksek lisans tezi). Ortadoğu Teknik Üniversitesi, Ankara.

Seferoğlu, S. ve Akbıyık, C. (2005). İlköğretim öğretmenlerinin bilgisayara yönelik öz-yeterlik algıları üzerine bir çalışma. Eğitim Araştırmaları Dergisi, 19, 89-101.

Sever, R. ve Yalçınkaya, E. (2012). Sınıf öğretmeni adaylarının çevresel tutumlarının incelenmesi. Marmara Coğrafya Dergisi, 26, 1-15.

Şahin, H. G. ve Doğu, S. (2018). Okul öncesi öğretmen adaylarının çevre sorunlarına ilişkin tutum ve davranıșlarının incelenmesi. Illkögretim Online, 17(3), 1402-1416.

Şama, E. (2003). Öğretmen adaylarının çevre sorunlarına yönelik tutumları. G. Ü. Gazi Ĕ̆itim Fakültesi Dergisi, 23(2), 99-110.

Şişman, M. (2009). Öğretmen yeterlilikleri: Modern bir söylem ve retorik. İnönü Üniversitesi Eğitim Fakültesi Dergisi, 10(3), 63-82.

Tahiroğlu, M., Yıldırım, T. ve Çetin, T. (2010). Değer eğitimi yöntemlerine uygun geliştirilen çevre eğitimi etkinliğinin, ilköğretim 7. sınıf öğrencilerinin çevreye ilişkin tutumlarına etkisi. Selçuk Üniversitesi Ahmet Keleşoğlu Ĕ̌itim Fakültesi Dergisi, 30, 231-248.

Tikka, P.M., Kuitunen, M.T. ve Tynys, S.M. (2000). Effects of educational background on students' attitudes, activity levels, and knowledge concerning the environment. Journal of Environmental Education, 31(3), 12-19.

Tschannen-Moran, M. ve Hoy, A.W. (2001). Teacher efficacy: Capturing an elusive construct. Teaching and Teacher Education, 17(7), 783-805.

Willuweit, L. (2009). Promoting pro-environmental behavior an investigation of the cross-cultural environmental behavior patterns. The case of Abu Dhabi. Unpublished master thesis, Stockholm University, Stockholm.

Yeşilyurt, S., Gül, Ş. ve Demir, Y. (2013). Biyoloji öğretmen adaylarının çevre bilinci ve çevresel duyarlılığı: Ölçek geliştirme çalışması. Mehmet Akif Üniversitesi Ĕ̈itim Fakültesi Dergisi, 13(25), 38-54.

Yıldız, K., Sipahioğlu, Ş. ve Yılmaz, M. (2000). Çevre bilimi. Ankara: Gündüz Eğitim ve Yayıncılık.

Yüksek Öğretim Kurumu [YÖK] (2018). Sınıf öğretmenliği lisans programı. Ankara.

Zajacova, A., Lynch, S.M. and Espenshade, T. J. (2005). Self-efficacy, stress, and academic success in college. Research in Higher Education, 46(6), 677-706. 


\title{
Investigating of Preservice Elementary Teachers' Environmental Self-Efficacy Perceptions in Terms of Various Variables
}

\author{
Seda OKUMUŞ \\ Atatürk Üniversitesi, Kazım Karabekir Eğitim Fakültesi, Matematik ve Fen Bilimleri Eğitimi Bölümü, Fen \\ Bilgisi Eğitimi ABD, Erzurum e-posta: seda.okumus@atauni.edu.tr \\ Bilge ÖZTÜRK \\ Bayburt Üniversitesi Matematik ve Fen Bilimleri Eğitimi Bölümü, Fen Bilgisi Eğitimi ABD, Bayburt, e- \\ posta:bilgeozturk25@gmail.com
}

Citation: Okumuş, S. ve Öztürk, B. (2019). Investigating of preservice elementary teachers' environmental selfefficacy perceptions in terms of various variables. E-Kafkas Journal of Educational Research, 6(2), 9-18.

\section{Extended Summary}

\section{Purpose}

Environmental education aims to raise awareness and inform all individuals about the environment (Güler, 2009) and to gain certain behavioral changes. Within the scope of these objectives, by creating a good selfefficacy perception in the environment, it will be ensured to raise generations more sensitive to the environment. Time is running against humanity day by day and depending on the time, the impact of people on the environment increases and differs from year to year and from region to region. The increasing number of problems in the environment becomes inevitable as a result of being insufficient on creating awareness about the environment. So that, it arouses curiosity how the result of Aydın's (2008) study with pre-service elementary teachers (PET) changes or if they change or not. The aim of this study was to determine the PETs' self-efficacy towards environmental education in terms of various variables.

\section{Method}

In the research, the survey design was used. The sample of the study consisted of 274 PETs who are studying at different grade levels (74 PETs from $1^{\text {st }}$ grade, 72 PETs from $2^{\text {nd }}$ grade, 65 PETs from $3^{\text {rd }}$ grade and 63 PETs from $4^{\text {th }}$ grade) of Bayburt University Faculty of Education Elementary Education Undergraduate Program. In this study, the convenience sampling method was used for sample selection. In order to collect data, Environmental Education Self-Efficacy Perception Scale (EESPS) which was developed by Aydın and Akar Vural (2009) was used. The EESPS consisted of four sub-scales as Academic Competence Perception- ACP, Responsibility Perception- RP, Instructive Competence Perception- ICP, and Guidance Perception- GP. The reliability of the EESPS was calculated again by researchers and the whole reliability of the EESPS found as .81 . For subscales, the reliability was calculated and $\alpha$ was found as. 85 for ACP and RP, .88 for ICP and .80 for GP. For the analysis of the data obtained from EESPS, firstly, normality analysis was performed, the KolmogorovSmirnov normality test was applied. Then, One-way ANOVA, Kruskal-Wallis, and Independent Sample t-test were used for significance analysis.

\section{Results}

In this study, PETs' self-efficacy perceptions about environmental education were examined in terms of grade level and gender variable. In the first sub-problem of the study, self-efficacy perceptions of PETS about environmental education were examined in terms of grade level. Accordingly, no statistically significant difference was observed among the groups in terms of class levels ( $p>0.05$ ). Also, in the analysis in terms of sub-scales, there was no statistically significant difference in the perception of environmental self-efficacy of PETs according to grade levels ( $p>0.05$ ). In the second sub-problem of the study, self-efficacy perceptions of PETs about environmental education were examined in terms of gender. Accordingly, no statistically significant difference was determined between all male and female PETs at each grade level in terms of environmental education selfefficacy perception ( $p>0.05)$.

\section{Conclusion}

Environmental education course is taught at the second-grade level and the fall semester in the elementary teacher education undergraduate program. Therefore, as the research was conducted in the spring semester, only the first-grade students who participated in the research do not have the environmental education course. In this respect, a significant difference was expected among the PETs who have environmental education course and those who do not have. However, there was no significant difference according to grade level. The lessons that the PETs have about the environment beforehand can be effective to arise in this situation. According to the sub-scales it was determined that PETs' perceptions of academic competence, responsibility, instructional competence and guidance about the environment were similar. Similar results have been reported in Deniş and Genç (2007) and Karademir's (2016) studies. Parallel to the results of this study, gender did not have an effect on environmental selfefficacy perceptions in Aydın (2008), Kahyaoğlu (2011) and Karademir's (2016) studies. 